\title{
Pharmacokinetic and pharmacodynamic profiles of subcutaneous administration of continuous erythropoietin receptor activator in lung cancer patients with anemia induced by chemotherapy
}

\author{
TOSHIAKI TAKAHASHI ${ }^{1}$, NOBUYUKI YAMAMOTO ${ }^{1}$, TOMOHIDE TAMURA $^{2}$, \\ HIDEO KUNITOH $^{2,5}$, YUTAKA NISHIWAKI ${ }^{3}$ and SHUNICHI NEGORO ${ }^{4}$ \\ ${ }^{1}$ Division of Thoracic Oncology, Shizuoka Cancer Center, Shizuoka 411-8777; \\ ${ }^{2}$ Department of Internal Medicine, National Cancer Center Hospital, Tokyo 104-0045; ${ }^{3}$ Thoracic Oncology Division, \\ National Cancer Center Hospital East, Chiba 277-8577; ${ }^{4}$ Thoracic Oncology, Hyogo Cancer Center, Hyogo 673-8558, Japan
}

Received March 12, 2011; Accepted July 15, 2011

DOI: 10.3892/ol.2011.398

\begin{abstract}
Continuous erythropoietin receptor activator (C.E.R.A.) is an innovative erythropoiesis-stimulating agent with unique erythropoietin receptor activity and a prolonged half-life. C.E.R.A. is currently in development for the correction of anemia and stable hemoglobin ( $\mathrm{Hb})$ control at extended administration intervals in patients with cancer who are receiving chemotherapy. The purpose of this pharmacological study was to evaluate the pharmacokinetic (PK), pharmacodynamic (PD) and safety profiles of C.E.R.A. administered subcutaneously once every 3 weeks (Q3W) in lung cancer patients with anemia induced by chemotherapy. This open-label, multicenter study recruited 46 patients. Entry $\mathrm{Hb}$ levels were not more than $11.0 \mathrm{~g} / \mathrm{dl}$. Five dose levels of C.E.R.A. $(2.1,4.2,6.3,9$ and $12 \mu \mathrm{g} / \mathrm{kg})$ were tested in sequential cohorts of 8-11 patients for 12 weeks. The mean values for C.E.R.A half-life ranged from 143 to $247 \mathrm{~h}$. The maximum serum concentration $\left(\mathrm{C}_{\max }\right)$ following the first administration of C.E.R.A. increased in proportion to the dose. The increase of $\mathrm{Hb}$ levels occurred in a dose-dependent manner. No serious adverse events reported as being related to C.E.R.A. were observed during the study period. Thrombovascular events were not observed in any patient. Anti-C.E.R.A antibodies were not detected in any patient. Thus, this pharmacological study confirmed the long half-life of C.E.R.A., thereby supporting subcutaneous administration of C.E.R.A. at the Q3W interval. $\mathrm{PK}$ and PD parameters demonstrated dose-proportionality over
\end{abstract}

Correspondence to: Dr Toshiaki Takahashi, Division of Thoracic Oncology, Shizuoka Cancer Center, 1007 Shimonagakubo Nagaizumi-cho Sunto-gun, Shizuoka 411-8777, Japan

E-mail: t.takahashi@scchr.jp

Present address: ${ }^{5}$ Department of Respiratory Medicine, Mitsui Memorial Hospital, Tokyo 101-8643, Japan

Key words: anemia, erythropoietin, chemotherapy, pharmacokinetic, pharmacodynamic the range of doses tested in this study. Additionally, C.E.R.A. was generally well tolerated.

\section{Introduction}

Erythropoiesis-stimulating agents (ESAs) are commonly used to treat chemotherapy-induced anemia. The administration of these agents has been shown to be effective for treating anemia in patients who undergo chemotherapy. These agents are effective as they increase hemoglobin $(\mathrm{Hb})$ concentrations and reduce or eliminate the need for red blood cell (RBC) transfusions, thus improving quality of life (QoL) (1-3). In anemic patients with cancer, ESAs were initially administered 3 times weekly, a schedule that had already proved effective in patients with renal anemia $(4,5)$. Once-weekly (Q1W) administration with all ESAs has become the preferred treatment modality $(6,7)$. Darbepoetin $\alpha$ has also been licensed for use once every 3 weeks (Q3W) in cancer patients with chemotherapy-induced anemia (8). Continuous erythropoietin receptor activator (C.E.R.A.) is an innovative agent with a prolonged half-life compared with that of epoetin $\alpha$ and epoetin $\beta$ in healthy volunteers, and darbepoetin $\alpha$ in patients with peritoneal dialysis (9). C.E.R.A. is a chemically synthesized continuous erythropoietin receptor activator that differs from erythropoietin through the integration of amide bonds between amino groups and methoxy polyethylene glycolsuccinimidyl butanoic acid $(10,11)$. It has been developed to provide correction of anemia and to control $\mathrm{Hb}$ levels at extended administration intervals in patients with CKD on dialysis and not on dialysis (9). Moreover, C.E.R.A. is currently in development for the correction of anemia and stable control of $\mathrm{Hb}$ levels at Q1W and Q3W administration intervals in cancer patients with chemotherapy-induced anemia. In preclinical studies and studies in healthy subjects, C.E.R.A. had a lower systemic clearance and an increased elimination half-life compared with conventional ESAs, and superior potency in vivo with respect to the magnitude and duration of response $(12,13)$. An exploratory Phase I-II dose-escalation study in anemic patients with multiple myeloma receiving myelosuppressive chemotherapy confirmed the long half-life 
of C.E.R.A. Additionally, a dose-dependent increase in $\mathrm{Hb}$ response was observed with C.E.R.A. doses up to $8.0 \mu \mathrm{g} / \mathrm{kg}$ when administered Q3W by subcutaneous (SC) injection (14). Moreover, two Phase II dose-finding studies were carried out in anemic patients with aggressive non-Hodgkin's lymphoma and advanced non-small cell lung cancer (NSCLC) receiving myelosuppressive chemotherapy $(15,16)$. A dose-dependent increase in $\mathrm{Hb}$ response was observed with C.E.R.A. doses up to $6.3 \mu \mathrm{g} / \mathrm{kg}$ when administered Q3W by SC injection. Notably, there was a trend to higher mean $\mathrm{Hb}$ increases and lower transfusion use in the $\mathrm{Q} 3 \mathrm{~W}$ groups as compared to the Q1W groups with respect to the NSCLC study. However, further dose-finding studies that use higher doses and allow dose escalation are required to determine the optimal C.E.R.A. Q3W dose regimen was administered in anemic cancer patients receiving chemotherapy as a limited effect was obtained even at the highest dose level of $6.3 \mu \mathrm{g} / \mathrm{kg}$ used in aggressive non-Hodgkin's lymphoma (15) and advanced non-small cell lung cancer (NSCLC) (16). Additonally, with regards to safety, neither dose-dependence in adverse events nor dose-limiting toxicity was observed at the dose level of $8.0 \mu \mathrm{g} / \mathrm{kg}(14)$.

This multicenter, open-label study was designed to evaluate the pharmacokinetic (PK)/pharmacodynamic (PD) properties and safety of five different dose levels of C.E.R.A. administered subcutaneously Q3W for up to 12 weeks in Japanese lung cancer patients with anemia induced by myelosuppressive chemotherapy.

\section{Patients and methods}

Patients. A total of 47 adult patients, aged $\geq 20$ and $<80$ years at the time of registration, were recruited based on the following criteria: patient is diagnosed with lung cancer by tissue or cytological examination, receiving cyclic chemotherapy for $\leq 4$ weeks as 1 cycle, and capable of undergoing chemotherapy within 3 days following the start of administration of the investigational medication. Patients were also required to have $\mathrm{Hb}$ levels $\leq 11.0 \mathrm{~g} / \mathrm{dl}$ at the registration examination, a life expectancy of $\geq 4$ months, Eastern Cooperative Oncology Group (ECOG) performance status grades of $0-2$, a satisfactory mean corpuscular volume (MCV), and to meet transferrin saturation (Tsat), hepatic and renal function criteria $[\mathrm{MCV} 80 \mathrm{fl}$ or higher, transferrin saturation $[\{\mathrm{Fe} /$ $(\mathrm{Fe}+\mathrm{UIBC})\} \times 100]$ of $15 \%$ or higher, total bilirubin value in serum: $\leq 2.0 \mathrm{mg} / \mathrm{dl}$, AST [GOT], ALT [GPT]: $80 \mathrm{IU} / \mathrm{l}$ or lower, serum creatinine value: $<2.0 \mathrm{mg} / \mathrm{dl}]$. Exclusion criteria included transfusion within 4 weeks prior to the planned start of administration of the investigational medication; severe hypertension uncontrollable by pharmaceutical products; marked hemorrhagic lesions possibly affecting evaluation in the clinical study or presence of serious complications; pregnant or nursing women, who were premenopausal and tested positive for pregnancy in a pregnancy test; expression of lack of intention to use contraception; history/complication of cardiac infarction, pulmonary infarction or cerebral infarction (excluding asymptomatic cerebral infarction); and serious medication allergy including anaphylactic shock. Patients recruited had not received treatment with ESAs within the 4 weeks prior to registration. The design and conduct of the study complied with the ethical principles of good clinical practice, in accordance with the Declaration of Helsinki. The study was approved by an independent institutional review board at each cancer center, and all 47 patients provided written informed consent prior to enrollment.

Study medication. Three separate strength vials were available $(200,400$ or $1000 \mu \mathrm{g} / \mathrm{ml})$, each containing a $1 \mathrm{ml}$ solution of C.E.R.A.

Study design. This was an open-label, multicenter, clinical pharmacology study that involved SC injections of C.E.R.A. over a 12-week treatment period, and a follow-up period for 3 weeks following the last administration of C.E.R.A. Patients were assigned sequentially according to increasing dose rotations to one of five groups, receiving C.E.R.A. at 2.1, 4.2, 6.3, 9 or $12 \mu \mathrm{g} / \mathrm{kg}$. This was administered Q3W by SC injection for 12 weeks. If $\mathrm{Hb}$ levels recovered to $>13.0 \mathrm{~g} / \mathrm{dl}$, treatment was discontinued. Chemotherapy and radiotherapy were used concomitantly during the period from the day of starting administration to the time of the last observation. Blood transfusions were performed concurrently in patients who did not show improvement in anemia and were judged clinically to require blood transfusion. Oral iron supplementation was administered daily during the administration period of the study medication if MCV was $<80 \mathrm{fl}$ or Tsat was $<15 \%$. Blood samples for detection of the C.E.R.A. antibody were collected prior to the first administration and within a maximum of 50 days following the final administration.

Serum assay. To determine PK parameters, blood samples were collected immediately prior to and 1, 8, 15, 22, 23-26, $27,29,32,36,43,64$ and 85 days following the initial administration of C.E.R.A. To investigate concentrations over time, samples were also collected immediately prior to the administration of each dose. Blood samples were allowed to stand at room temperature for $30 \mathrm{~min}$ and were then centrifuged at $4^{\circ} \mathrm{C}$ and 3,000 rpm for $10 \mathrm{~min}$ to separate the serum. The resulting serum was stored below $-20^{\circ} \mathrm{C}$ until used for the measurement of serum C.E.R.A. concentrations. Serum concentrations of C.E.R.A. were measured by a validated enzyme-linked immunosorbent assay using a primary monoclonal antibody specific to C.E.R.A. that did not cross-react with endogenous erythropoietin, and a secondary polyclonal anti-immunoglobulin antibody coupled to horseradish peroxidase (Huntingdon Life Sciences, Alconbury, UK). The assay range was 150 to $4000 \mathrm{pg} / \mathrm{ml}$. The inter-batch assay precision was 7.8 to $11.4 \%$, and accuracy was -7.8 to $-6.6 \%$. The assay is specific to C.E.R.A. and does not detect human erythropoietin, and human erythropoietin does not interfere with the assay.

Pharmacokinetic analyses. Serum concentrations of C.E.R.A. were used to determine the maximum serum concentration $\left(\mathrm{C}_{\max }\right)$ and time to maximum serum concentration $\left(\mathrm{T}_{\max }\right)$. The $t_{1 / 2}$ was estimated for $\ln (2) / k$, where the rate constant of elimination (k) was determined by linear regression of the logarithm of the serum concentration vs. time data in the post-distribution phase. The area under the concentration-time curve (AUC) following C.E.R.A. administration, from predose on day 22 until the last sampling time at which the 


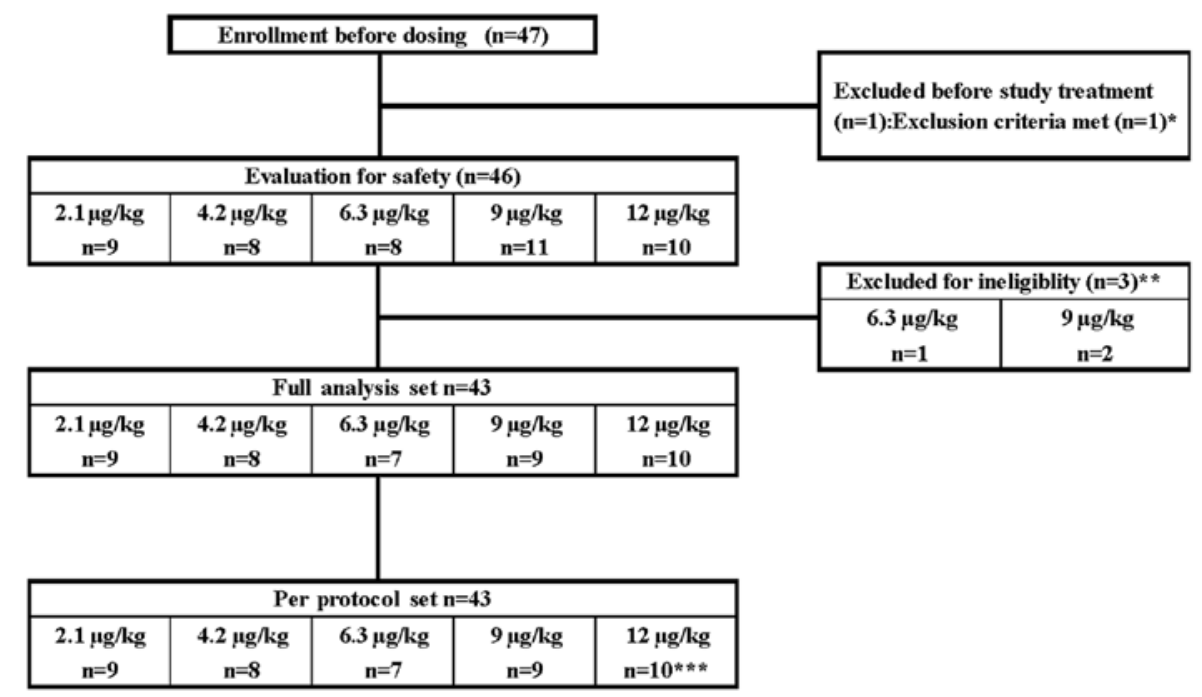

Figure 1. Patient conditions.. One patient did not receive study medication for the development of ileus. " One patient allocated to the $6.3 \mu \mathrm{g} / \mathrm{kg}$ dose group and two patients allocated to $9 \mu \mathrm{g} / \mathrm{kg}$ dose group were excluded from the data analyses caused by the defect of medication vials. ${ }^{* * * *} \mathrm{One}$ patient in the $12 \mu \mathrm{g} / \mathrm{kg}$ dose group was excluded from the data analyses following week 7 , caused by a defect in medication vials.

concentration was measurable (day 43), was estimated by the linear trapezoidal rule.

Pharmacodynamic analyses. The PD parameters involved the change in $\mathrm{Hb}$ from the nadir value. The change in the $\mathrm{Hb}$ level from the nadir value was calculated by subtraction of the nadir value over the period weeks 1-4 from the $\mathrm{Hb}$ value at week 7 . The increase in $\mathrm{Hb}$ produced by C.E.R.A. administration was estimated to occur over the 4 weeks following first administration of C.E.R.A. and certain patients were withdrawn from the study after 6 weeks (17). Moreover, to estimate the increase of $\mathrm{Hb}$ caused by C.E.R.A., the effect of chemotherapy on $\mathrm{Hb}$ was removed. Therefore, to evaluate the effect of C.E.R.A. on $\mathrm{Hb}$ levels, the change in $\mathrm{Hb}$ was calculated between the nadir values from weeks 1-4 and the values at week 7 .

Safety. Safety endpoints included adverse events, clinical laboratory tests, vital signs, body weight, physical examination and ECGs. The intensities of adverse events and laboratory values were graded according to the National Cancer Institute/Common Terminology Criteria for Adverse Events v3.0 (CTCAE).

Statistical analysis. Mean, standard deviation, and the coefficient of variation of the PK parameters were calculated for each treatment. Mean, standard deviation, median, range and standard error are provided per day for Hb levels. Descriptive statistics were calculated using SAS (version 9.1.3). Figures were prepared with S-Plus (version 8.1).

\section{Results}

Patients. A total of 47 lung cancer patients were enrolled (Fig. 1). Treatment of one patient assigned to the $9 \mu \mathrm{g} / \mathrm{kg}$ dose group was discontinued due to the development of ileus prior to the first administration. The remaining 46 patients were treated with each dose of C.E.R.A. and were included in the safety populations. In total, 46 patients completed the study treatment period. However, one patient assigned to the $6.3 \mu \mathrm{g} /$ $\mathrm{kg}$ dose group and two patients assigned to the $9 \mu \mathrm{g} / \mathrm{kg}$ dose group were excluded from the PK and PD analyses due to defects in the study medication, which included vial blistering and contents out of specification. The remaining 43 patients were included in the analysis of full analysis set and per protocol set populations. However, one patient in the $12 \mu \mathrm{g} /$ $\mathrm{kg}$ dose group was excluded from the data analysis following week 7 due to a defect in the medication vial. Doses were held for a total of 25 patients. Consequently, these patients were not administered the full four doses of the study medication during the 12-week period. The reasons for discontinuation of the study medication were progressive disease, $\mathrm{Hb}$ levels $>13 \mathrm{~g} / \mathrm{dl}$, Hb level elevation of $\geq 2.0 \mathrm{~g} / \mathrm{dl}$ from previous treatment to next treatment and termination of concomitant chemotherapy.

Baseline characteristics and demographics are shown in Table I. Patients had received chemotherapy prior to the start of this study. A total of 11, 13, 25, 18 and $10 \%$ of patients had undergone surgery and 33,50,13,18 and $20 \%$ of patients had undergone radiotherapy in the $2.1,4.2,6.3,9$ and $12 \mu \mathrm{g} / \mathrm{kg}$ dose groups, respectively. Median $\mathrm{Hb}$ levels ranged from 8.9 to $10.5 \mathrm{~g} / \mathrm{dl}$ across all dose groups. The values for iron parameters in the 9 and $12 \mu \mathrm{g} / \mathrm{kg}$ dose groups at baseline were lower than those in the 2.1, 4.2 and $6.3 \mu \mathrm{g} / \mathrm{kg}$ dose groups.

Patients received at least one chemotherapy cycle within 3 days following the initial C.E.R.A. administration, which was most commonly platinum-based chemotherapy (the percentage of carboplatin or cisplatin treatments: 78, 63, 43, 78 and $40 \%$ in the $2.1,4.2,6.3,9$ and $12 \mu \mathrm{g} / \mathrm{kg}$ dose groups, respectively). Other common chemotherapies included amrubicin hydrochloride $(11,13,29,0$ and $60 \%$ in the 2.1, 4.2, 6.3, 9, and $12 \mu \mathrm{g} / \mathrm{kg}$ dose groups, respectively) and docetaxel hydrate $(11,25,29,22$ and $0 \%$ in the $2.1,4.2,6.3,9$ and $12 \mu \mathrm{g} / \mathrm{kg}$ dose groups, respectively) (Table II).

Overall, 22 patients received oral iron therapy. The percentage of patients receiving concomitant oral iron supplementation was higher in the 9 and $12 \mu \mathrm{g} / \mathrm{kg}$ dose 
Table I. Summary of patient's baseline characteristics (range or \%): safety population.

\begin{tabular}{|c|c|c|c|c|c|}
\hline & \multicolumn{5}{|c|}{ C.E.R.A. dose group ( $\mu \mathrm{g} / \mathrm{kg}$ Q3W) } \\
\hline & $\begin{array}{c}2.1 \mu \mathrm{g} / \mathrm{kg} \\
\mathrm{n}=9\end{array}$ & $\begin{array}{c}4.2 \mu \mathrm{g} / \mathrm{kg} \\
\mathrm{n}=8\end{array}$ & $\begin{array}{c}6.3 \mu \mathrm{g} / \mathrm{kg} \\
\mathrm{n}=8\end{array}$ & $\begin{array}{c}9 \mu \mathrm{g} / \mathrm{kg} \\
\mathrm{n}=11\end{array}$ & $\begin{array}{c}12 \mu \mathrm{g} / \mathrm{kg} \\
\mathrm{n}=10\end{array}$ \\
\hline \multicolumn{6}{|l|}{ Gender $(\%)$} \\
\hline Male & $6(67)$ & $8(100)$ & $4(50)$ & $8(73)$ & $8(80)$ \\
\hline Female & $3(33)$ & 0 & $4(50)$ & $3(27)$ & $2(20)$ \\
\hline Median age, years & $59(53-79)$ & $67(59-76)$ & $64(34-72)$ & $67(50-77)$ & $71(56-79)$ \\
\hline Median body weight (kg) & $60(53-75)$ & $56(47-66)$ & $58(48-61)$ & $56(44-75)$ & $52(44-66)$ \\
\hline \multicolumn{6}{|l|}{ ECOG PS (\%) } \\
\hline 0 & $5(56)$ & $1(12)$ & $6(75)$ & $2(18)$ & $3(30)$ \\
\hline 1 & $4(44)$ & $7(88)$ & $2(25)$ & $9(82)$ & $7(70)$ \\
\hline 2 & 0 & 0 & 0 & 0 & 0 \\
\hline \multicolumn{6}{|l|}{ History of lung cancer } \\
\hline Small cell & $2(22)$ & $3(38)$ & $5(63)$ & $2(18)$ & $6(60)$ \\
\hline Non-small cell & $7(78)$ & $5(62)$ & $3(37)$ & $8(73)$ & $4(40)$ \\
\hline Mixed type & 0 & 0 & 0 & $1(9)$ & 0 \\
\hline \multicolumn{6}{|l|}{ Previous treatment $(\%)$} \\
\hline Chemotherapy & $9(100)$ & $8(100)$ & $8(100)$ & $11(100)$ & $10(100)$ \\
\hline Surgery & $1(11)$ & $1(13)$ & $2(25)$ & $2(18)$ & $1(10)$ \\
\hline Radiotherapy & $3(33)$ & $4(50)$ & $1(13)$ & $2(18)$ & $2(20)$ \\
\hline Transfusion & 0 & $1(13)$ & $1(13)$ & 0 & 0 \\
\hline Median Hb level (g/dl) & $9.2(7.7-10.5)$ & $10.0(9.3-10.8)$ & $10.5(8.8-10.9)$ & $8.9(7.2-10.4)$ & $10.0(8.1-11.8)$ \\
\hline $\begin{array}{l}\text { Median serum } \\
\text { ferritin }(\mathrm{ng} / \mathrm{ml})\end{array}$ & $516(85-800)$ & $392(147-771)$ & $139(10-2100)$ & $340(13-647)$ & $286(55-651)$ \\
\hline $\begin{array}{l}\text { Median serum } \\
\mathrm{Fe}(\mu \mathrm{g} / \mathrm{dl})\end{array}$ & $72(33-111)$ & $68(22-75)$ & $76(19-123)$ & 49 (19-70) & 47 (15-69) \\
\hline Median Tsat (\%) & $24.3(11.0-46.3)$ & $25.8(10.0-35.4)$ & $28.0(6.7-42.7)$ & $18.7(10.0-31.0)$ & $16.3(8.4-27.6)$ \\
\hline
\end{tabular}

Table II. Summary of patient's baseline Hb level, reticulocyte counts and oral supplementation and combination chemotherapy (range or \%): PPS population.

\begin{tabular}{|c|c|c|c|c|c|}
\hline & \multicolumn{5}{|c|}{ C.E.R.A. dose group ( $\mu \mathrm{g} / \mathrm{kg}$ Q3W) } \\
\hline & $\begin{array}{c}2.1 \mu \mathrm{g} / \mathrm{kg} \\
\mathrm{n}=9\end{array}$ & $\begin{array}{c}4.2 \mu \mathrm{g} / \mathrm{kg} \\
\mathrm{n}=8\end{array}$ & $\begin{array}{c}6.3 \mu \mathrm{g} / \mathrm{kg} \\
\mathrm{n}=7\end{array}$ & $\begin{array}{c}9 \mu \mathrm{g} / \mathrm{kg} \\
\mathrm{n}=9\end{array}$ & $\begin{array}{c}12 \mu \mathrm{g} / \mathrm{kg} \\
\mathrm{n}=10\end{array}$ \\
\hline Reticulocyte counts $\times 10^{4} / \mathrm{mm}^{3}$ & $9.4(3.3-12.5)$ & $8.0^{\mathrm{a}}(4.3-15.0)$ & $9.4(3.3-12.5)$ & $6.6(3.2-11.2)$ & $6.0(2.6-10.4)$ \\
\hline $\begin{array}{l}\text { Oral iron supplementation } \\
\text { during treatment }(\%)\end{array}$ & $3(33)$ & $3(38)$ & $3(33)$ & $8(89)$ & $5(50)$ \\
\hline \multicolumn{6}{|l|}{ Chemotherapy, n, (\%) } \\
\hline Platinums $^{\mathrm{b}}$ & $4(44)$ & $4(50)$ & $4(44)$ & $5(55)$ & $3(30)$ \\
\hline Platinums + taxanes & & $3(33)$ & 0 & $2(22)$ & $1(10)$ \\
\hline Non-platinums & $2(22)$ & $3(38)$ & $2(22)$ & $2(22)$ & $6(60)$ \\
\hline Taxanes & $1(11)$ & $2(25)$ & $1(11)$ & $2(22)$ & 0 \\
\hline Anthracyclines & $1(11)$ & $1(13)$ & $1(11)$ & 0 & $6(60)$ \\
\hline
\end{tabular}




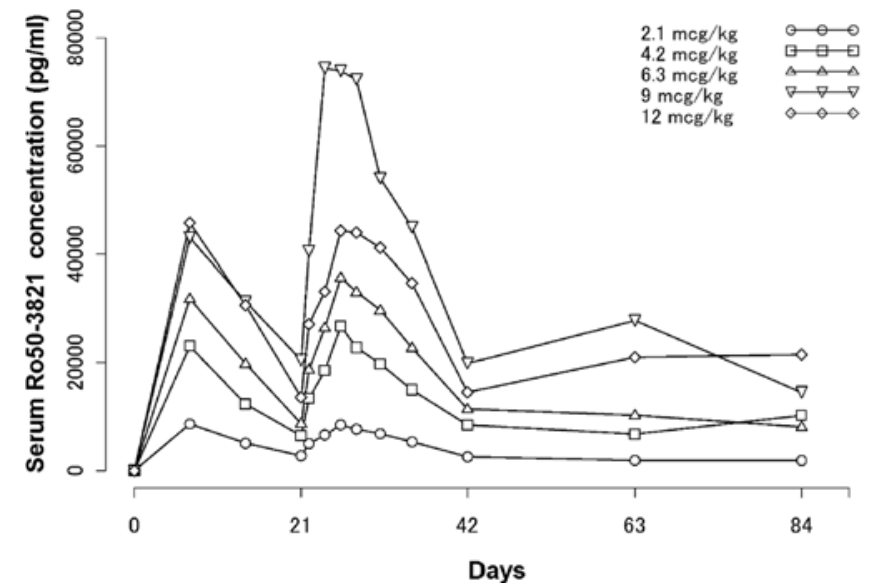

Figure 2. Serum C.E.R.A. concentration profiles (the mean \pm SD).

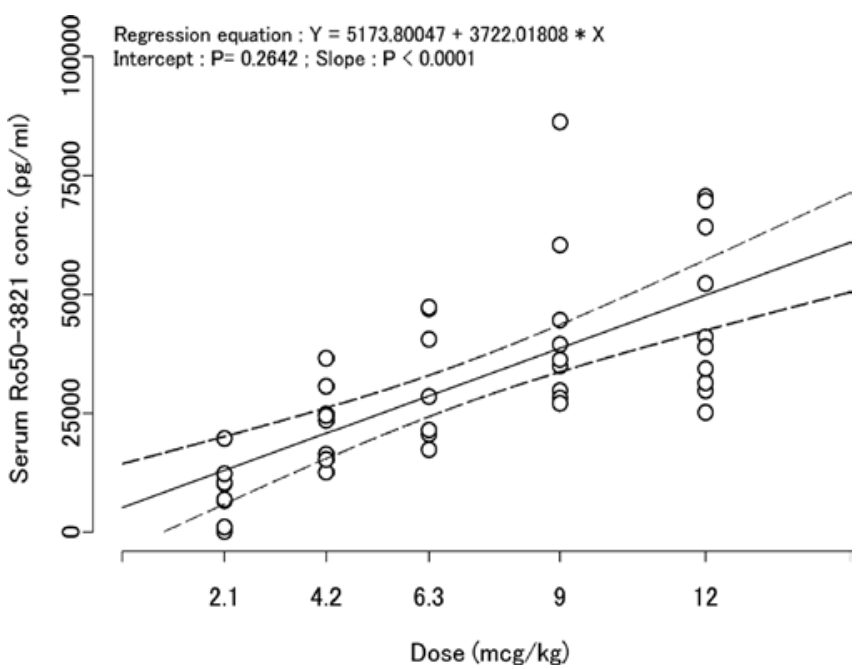

Figure 3. Correlation between dose and $\mathrm{C}_{\max }$ following the initial dosing.

groups (89 and 50\%, respectively) compared with the 2.1, 4.2 and $6.3 \mu \mathrm{g} / \mathrm{kg}$ dose groups (33, 38 and $43 \%$, respectively) (Table II).

Pharmacokinetic analyses. Serum C.E.R.A. concentrationtime profiles from weeks 1-13 are shown in Fig. 2. PK parameters were estimated following the second dosing and the correlation between dose and $\mathrm{C}_{\max }$ was estimated following the initial dosing. PK parameter values are shown in Table III. Serum concentrations of C.E.R.A. following the second administration in the 2.1, 4.2, 6.3, 9 and $12 \mu \mathrm{g} / \mathrm{kg}$ dose groups reached $\mathrm{C}_{\max }$ at 119 to $167 \mathrm{~h}$ (mean); the drug was then eliminated with half-lives $\left(\mathrm{t}_{1 / 2}\right)$ of 143 to $217 \mathrm{~h}$, respectively (median). $\mathrm{T}_{\max }$ values were similar among the dose groups. $\mathrm{T}_{1 / 2}$ values were shown to be high across the dose groups and appeared to show no major differences among the dose groups.

$\mathrm{AUC}_{\text {inf }}$ in the 2.1, 4.2, 6.3, 9 and $12 \mu \mathrm{g} / \mathrm{kg}$ dose groups were $4060 \pm 2380,12000 \pm 5580,16100 \pm 7220,30100 \pm 12500$ and $23400 \pm 8080 \mathrm{ng} \bullet \mathrm{h} / \mathrm{ml}$, respectively. $\mathrm{C}_{\max }$ values were $9.09 \pm 5.26$, $27.4 \pm 7.63, \quad 38.9 \pm 13.9, \quad 84.6 \pm 36.0$ and $47.8 \pm 14.3 \mathrm{ng} / \mathrm{ml}$, respectively.
Table III. PK parameters following the second dosing.

\begin{tabular}{|c|c|c|c|}
\hline Parameter & Dose $(\mu \mathrm{g} / \mathrm{kg})$ & Mean \pm SD & No. \\
\hline \multirow[t]{5}{*}{$\mathrm{C}_{\max }(\mathrm{ng} / \mathrm{ml})$} & 2.1 & $9.09 \pm 5.26$ & 9 \\
\hline & 4.2 & $27.4 \pm 7.63$ & 8 \\
\hline & 6.3 & $38.9 \pm 13.9$ & 7 \\
\hline & 9 & $84.6 \pm 36.0$ & 9 \\
\hline & 12 & $47.8 \pm 14.3$ & 10 \\
\hline \multirow[t]{5}{*}{$\mathrm{T}_{\max }(\mathrm{h})$} & 2.1 & $146 \pm 43.1$ & 9 \\
\hline & 4.2 & $130 \pm 23.1$ & 8 \\
\hline & 6.3 & $119 \pm 43.6$ & 7 \\
\hline & 9 & $149 \pm 80.2$ & 9 \\
\hline & 12 & $167 \pm 42.6$ & 10 \\
\hline \multirow[t]{5}{*}{$\mathrm{AUC}_{\mathrm{t}}(\mathrm{ng} * \mathrm{~h} / \mathrm{ml})$} & 2.1 & $2730 \pm 1680$ & 9 \\
\hline & 4.2 & $8540 \pm 2430$ & 8 \\
\hline & 6.3 & $12100 \pm 4630$ & 7 \\
\hline & 9 & $23700 \pm 9470$ & 9 \\
\hline & 12 & $16200 \pm 5520$ & 10 \\
\hline \multirow[t]{5}{*}{$\mathrm{t}_{1 / 2}(\mathrm{~h})$} & 2.1 & $185(152-276)$ & 6 \\
\hline & 4.2 & 217 (176-279) & 8 \\
\hline & 6.3 & $175(165-182)$ & 6 \\
\hline & 9 & $143(126-163)$ & 7 \\
\hline & 12 & $162(159-237)$ & 7 \\
\hline \multirow[t]{5}{*}{$\mathrm{AUC}_{\mathrm{inf}}\left(\mathrm{ng}{ }^{*} \mathrm{~h} / \mathrm{ml}\right)$} & 2.1 & $4060 \pm 2380$ & 6 \\
\hline & 4.2 & $12000 \pm 5580$ & 8 \\
\hline & 6.3 & $16100 \pm 7220$ & 6 \\
\hline & 9 & $30100 \pm 12500$ & 7 \\
\hline & 12 & $23400 \pm 8080$ & 7 \\
\hline \multirow[t]{5}{*}{$\mathrm{C}_{\min }(\mathrm{pg} / \mathrm{ml})$} & 2.1 & $2900 \pm 1680$ & 8 \\
\hline & 4.2 & $8460 \pm 4000$ & 8 \\
\hline & 6.3 & $11400 \pm 5480$ & 7 \\
\hline & 9 & $19900 \pm 15200$ & 9 \\
\hline & 12 & $14500 \pm 7130$ & 10 \\
\hline \multirow[t]{5}{*}{$\mathrm{C}_{\mathrm{av}}(\mathrm{ng} / \mathrm{ml})$} & 2.1 & $3.74 \pm 2.85$ & 9 \\
\hline & 4.2 & $8.92 \pm 2.22$ & 8 \\
\hline & 6.3 & $12.3 \pm 4.4$ & 7 \\
\hline & 9 & $27.4 \pm 13.4$ & 9 \\
\hline & 12 & $19.5 \pm 6.68$ & 10 \\
\hline \multirow[t]{5}{*}{ MRT (day) } & 2.1 & $15.9 \pm 5.87$ & 6 \\
\hline & 4.2 & $16.7 \pm 5.74$ & 8 \\
\hline & 6.3 & $15 \pm 5.59$ & 6 \\
\hline & 9 & $10.9 \pm 1.74$ & 7 \\
\hline & 12 & $15.5 \pm 6.89$ & 7 \\
\hline
\end{tabular}

$\mathrm{t}_{1 / 2}: \operatorname{median}[\mathrm{Q} 1-\mathrm{Q} 3]$.

Exposure $\left(\mathrm{AUC}_{\mathrm{inf}}, \mathrm{C}_{\mathrm{max}}\right)$ was increased in proportion to the dose from the $2.1 \mu \mathrm{g} / \mathrm{kg}$ to the $9 \mu \mathrm{g} / \mathrm{kg}$ dose groups. On the other hand, no such increases were observed between the $9 \mu \mathrm{g} / \mathrm{kg}$ and $12 \mu \mathrm{g} / \mathrm{kg}$ dose groups. The $95 \%$ confidence interval for the $y$-intercept of the regression line between dose and $\mathrm{C}_{\max }$ was 0 (zero) (Fig. 3). 
Table IV. Most common reported adverse events related to study treatment (in $\geq 10 \%$ of patients in any treatment group).

\begin{tabular}{lcccccr}
\hline Adverse event, $\mathrm{n}(\%)$ & $\begin{array}{c}2.1 \mu \mathrm{g} / \mathrm{kg} \\
(\mathrm{n}=9)\end{array}$ & $\begin{array}{c}4.2 \mu \mathrm{g} / \mathrm{kg} \\
(\mathrm{n}=8)\end{array}$ & $\begin{array}{c}6.3 \mu \mathrm{g} / \mathrm{kg} \\
(\mathrm{n}=8)\end{array}$ & $\begin{array}{c}9 \mu \mathrm{g} / \mathrm{kg} \\
(\mathrm{n}=11)\end{array}$ & $\begin{array}{c}12 \mu \mathrm{g} / \mathrm{kg} \\
(\mathrm{n}=10)\end{array}$ & $\begin{array}{c}\text { Total } \\
(\mathrm{n}=46)\end{array}$ \\
\hline Potassium increase & $2(22.2)$ & $3(37.5)$ & - & $1(9.1)$ & $2(20.0)$ & $8(17)$ \\
Neutrophils decrease & $2(22.2)$ & $3(37.5)$ & $1(12.5)$ & - & - & $6(13)$ \\
WBC decrease & $3(33.3)$ & $3(37.5)$ & - & - & - & $6(13)$ \\
Lymphocytes decrease & $1(11.1)$ & $3(37.5)$ & $1(12.5)$ & - & - & $5(11)$ \\
Sodium increase & $2(22.2)$ & - & - & $1(9.1)$ & $2(20.0)$ & $5(11)$ \\
Diarrhea & $1(11.1)$ & - & $1(12.5)$ & - & $3(30.0)$ & $5(11)$ \\
Constipation & $3(33.3)$ & $2(25.0)$ & - & - & - & $5(11)$ \\
Headache & $1(11.1)$ & - & $3(37.5)$ & $1(9.1)$ & - & $5(11)$ \\
\hline
\end{tabular}

C.E.R.A., continuous erythropoietin receptor activator; Q3W, once every 3 weeks.

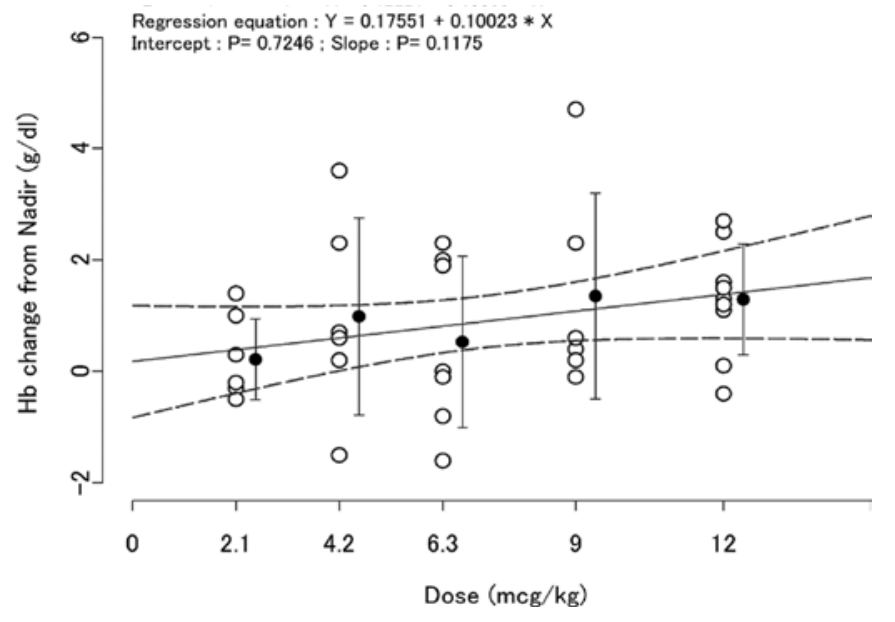

Figure 4. Correlation between the dose and change in $\mathrm{Hb}$ levels.

Photodynamic analyses. The change in $\mathrm{Hb}$ levels from the nadir value over the period weeks $1-4$ to week 7 values is shown in Fig. 4. The changes in $\mathrm{Hb}$ levels were above 0 (zero) in the dosing groups and the slope between the dose of C.E.R.A. and the change in $\mathrm{Hb}$ was greater than 0 (zero) (Fig. 4).

Safety and tolerability. Q3W administration of C.E.R.A. was generally well tolerated across the dose groups. All of the patients reported at least one adverse event. Most adverse events were those expected in cancer patients receiving chemotherapy, and none occurred in a manner dependent on the C.E.R.A. dose. The percentage of patients reporting adverse events in which a causal correlation with the study medication cannot be completely excluded were $89,75,88$, 64 and $40 \%$ in the $2.1,4.2,6.3,9$ and $12 \mu \mathrm{g} / \mathrm{kg}$ dose groups, respectively. The most common adverse events (incidence rate $\geq 10 \%$ ) related to the study medication were potassium increase (17\%), neutrophil decrease (13\%), WBC decrease (11\%), diarrhea (11\%), constipation (11\%) and headache $(11 \%)$. A total of 10 patients experienced grade 3-4 adverse events related to the study treatment including WBC decrease, febrile neutropenia, neutrophil decrease, $\mathrm{Hb}$ decrease, platelet decrease, lymphocyte decrease, potassium increase and sodium decrease (Table IV). No clinically significant changes occurred from baseline in laboratory values and vital signs during the study period in the dose groups, or dose-dependent correlations with increased blood pressure. One patient in the $6.3 \mu \mathrm{g} / \mathrm{kg}$ dose group experienced grade 2 hypertension possibly associated with C.E.R.A. treatment from the 1 st to the 14th day of the second administration. An antihypertensive medication was administered following the onset of hypertension. Blood pressure was then stabilized.

Serious adverse events were observed in one patient from each of the 4.2 and $6.3 \mu \mathrm{g} / \mathrm{kg}$ dose groups, and three patients in the $12 \mu \mathrm{g} / \mathrm{kg}$ dose group. Serious adverse events were evaluated as not related to the study medication.

Thrombovascular adverse events were not observed. Withdrawal of one patient in the $12 \mu \mathrm{g} / \mathrm{kg}$ dose group was attributed to disease progression and no mortality was reported during the study period. Moreover, no anti-C.E.R.A. antibodies were detected in any of the patients.

\section{Discussion}

Anemia is a frequent complication in patients with lung cancer who are administered chemotherapy $(18,19)$. Anemia has a profound impact on QoL, with fatigue being one of its common symptoms (20-22). Furthermore, the widespread use of platinum-based chemotherapy contributes further to the development of anemia in patients with lung cancer (23).

C.E.R.A. is a chemically synthesized continuous erythropoietin receptor activator with a prolonged serum half-life that has been shown to be safe and effective for the treatment of chemotherapy-induced anemia when administered using Q1W or Q3W administration schedules (16).

This is the first study to examine the PK, PD and safety profiles of C.E.R.A. treatment subcutaneously Q3W in Japanese patients with lung cancer and anemia induced by chemotherapy. This study demonstrated that C.E.R.A. subcutaneously administered to Japanese lung cancer patients showed exposure in accordance with dose increase and a long half-life. Exposure $\left(\mathrm{AUC}_{\mathrm{inf}}, \mathrm{C}_{\max }\right.$ ) following second administration increased with dose proportionality in the 2.1 to $9 \mu \mathrm{g} / \mathrm{kg}$ dose groups. On the 
other hand, exposure was not increased across the 9 to $12 \mu \mathrm{g} /$ $\mathrm{kg}$ dose groups. The reason for this non-linearity between dose and exposure may be due to the small number of patients, the verification of patient characteristics at baseline and the fact that the information was limited. It was considered to be reduced bioavailability from the $\mathrm{SC}$ injection site in the $12 \mu \mathrm{g} /$ $\mathrm{kg}$ dose group, as the $\mathrm{T}_{\max }$ values (an indicator of $\mathrm{SC}$ absorption rate) were similar among the dose groups and the $t_{1 / 2}$ values (indicator of elimination rate) also showed no major differences among the dose groups. A similar phenomenon was observed following SC injection of epoetin $\beta$ (24). Nakagawa et al reported that $\mathrm{C}_{\max }$ and $\mathrm{AUC}_{\text {inf }}$ following $\mathrm{SC}$ injection of epoetin $\beta$ to lung cancer patients increased with dose-proportionality from the 9000 to 36000 IU dose groups and were similar between the 36000 and 54000 IU dose groups (25). These authors also suggested that declining bioavailability of epoetin $\beta$ at higher doses is partially due to absorption following SC injection of this drug into the lymphatic system (26). The same mechanism may explain the reason for non-linearity between the dose of C.E.R.A. and levels of exposure, but further studies are required to clarify this non-linearity.

Median values for $t_{1 / 2}$ ranged from 143 to $217 \mathrm{~h}$ in this study. These results showed that the values for $t_{1 / 2}$ of C.E.R.A. were prolonged by 5-10 times compared with those reported for epoetin $\beta$ in patients with lung cancer $(24,25)$ or 2-4 times compared with those reported for darbepoetin $\alpha$ in patients with cancer (27).

Agoram et al suggested that the platinum-containing chemotherapy cycle count affected the clearance of darbepoetin $\alpha$ (28); thus, the PK parameters following the initial administration of C.E.R.A. were assessed to estimate the parameters under the same conditions of chemotherapy. Following the first C.E.R.A. administration, $\mathrm{C}_{\max }$ showed dose-proportionality as the $95 \%$ confidence interval for the $y$-intercept of the regression line between dose and $\mathrm{C}_{\max }$ was 0 (zero) (Fig. 3). These results suggested linear PKs of C.E.R.A. following SC administration, above the range of 2.1 to $12 \mu \mathrm{g} / \mathrm{kg}$.

In addition, changes in $\mathrm{Hb}$ levels from the nadir value over the period weeks 1-4 to week 7 values were observed (Fig. 4). The change in $\mathrm{Hb}$ levels was above 0 (zero) in all dose groups and the slope of the line relating dose of C.E.R.A. to the change of $\mathrm{Hb}$ was over 0 (zero). These results suggest that the SC administration of C.E.R.A. above the range of 2.1 to $12 \mu \mathrm{g} / \mathrm{kg}$ Q3W increased $\mathrm{Hb}$ levels in these patients and these increases were somewhat dose-dependent. The $\mathrm{Hb}$ responses supported results previously observed in studies with C.E.R.A. in cancer patients following SC Q3W administration $(15,16)$. Furthermore, the responses observed at doses of 9 and $12 \mu \mathrm{g} / \mathrm{kg}$ do not appear to have previously been reported.

All 46 patients receiving C.E.R.A. administration at least once were included in the safety analyses. C.E.R.A. was generally well tolerated across the dose groups, with adverse events that may be expected for patients with lung cancer receiving chemotherapy (e.g., neutrophil decrease), and these were similar to those reported for epoetin $\beta$ (24). The most common adverse events were those expected in a cancer population receiving chemotherapy. Adverse events reported with regards to the study medication were observed in $32(69.6 \%)$ patients. C.E.R.A. did not appear to have any adverse effects involving occurrence of thrombovascular events.
In conclusion, the dose proportionality observed regarding the PK and PD profiles and the good tolerability and safety profile in this study involving a small number of patients with lung cancer suggested that extended Q3W administration intervals are feasible in the clinic. However, further dosefinding studies may be required to determine the optimal C.E.R.A. dose regimen at Q3W in cancer patients with anemia induced by chemotherapy.

\section{Acknowledgements}

This study was funded by Chugai Pharmaceuticals Co. Ltd., Tokyo, Japan. Study medications were provided by Hoffmann-La Roche Inc. Responsibility for opinions, conclusions and interpretation of data lies with the authors.

\section{References}

1. Oberhoff C, Neri B, Amadori D, Perty KU, Gamucci T, Rebmann $\mathrm{U}$ and et al: Recombinant human erythropoietin in the treatment of chemotherapy induced anemia and prevention of transfusion requirement associated with solid tumors: a randomized, controlled study. Ann Oncol 9: 239-241, 1998.

2. Littlewood TJ, Bajetta E, Nortier JW, Vercammen E and Rapoport B: Epoetin Alfa Study Group: Effects of epoetin alfa on hematologic parameters and quality of life in cancer patients receiving nonplatinum chemotherapy; results of a randomized, double-blind, placebo-controlled trial. J Clin Oncol 19: 2865-2874, 2001.

3. Vansteenkiste J, Pirker R, Massuti B, Barata F, Font A, Fiegl M, Siena S, Gateley J, Tomita D, Colowick AB and Musil J: Double-blind placebo-controlled, randomized phase III trial of darbepoetin alfa in lung cancer patients receiving chemotherapy. J Natl Cancer Inst 94: 1211-1220, 2002.

4. Ludwig H, Fritz E, Kotzmann H, Hocker P, Gisslinger H and Barnus U: Erythropoietin treatment of anemia associated with multiple myeloma. N Engl J Med 322:1693-1699, 1990

5. Eshbach JW, Egrie JC, Dowing MR, Browne JK and Adamson JW: Correction of the anemia of end-stage renal disease with recombinant human erythropoietin. Results of a combined phases I and II clinical trial. N Engl J Med 316: 73-78, 1987.

6. Cazzola M, Beguin Y, Kloczko J, Spicka I and Coiffier B: Once-weekly epoetin beta is highly effective in treating anaemic patients with lymphoproliferative malignancy and defective endogenous erythropoietin production. $\mathrm{Br} \mathrm{J}$ Haematol 122: 386-393, 2003.

7. Waltzman R, Croot C, Justice GR, Fesen MR, Charu V and Williams D: Randomized comparison of epoetin alfa $(40,000$ U weekly) and darbepoetin alfa (200 microg every 2 weeks) in anemic patients with cancer receiving chemotherapy. Oncologist 10: 642-650, 2005

8. Canon JL, Vansteenkiste J, Bodoky G, Mateos MV, Bastit L, Ferreira I, Rossi G and Amado RG: Randomized, double-blind, active-controlled trial of every-3-week darbepoetin alfa for the treatment of chemotherapy-induced anemia. J Natl Cancer Inst 98: 273-284, 2006.

9. Locatelli $F$ and Reigner B: C.E.R.A. pharmacodynamics, pharmacokinetics and efficacy in patients with chronic kidney disease. Expert Opin Investig Drugs 16: 1649-1661, 2007.

10. Macdougall IC, Bailon P, Tare $\mathrm{T}$ and Pahlke W: CERA (Continuous Erythropoiesis Receptor Activator) for the treatment of renal anemia: an innovative agent with unique receptor binding characteristics and prolonged serum half-life. J Am Soc Nephrol 14: 769A (Abstract SU-PO 1063), 2003.

11. Macdougall IC: CERA (Continuous Erythropoietin Receptor Activator): a new erythropoiesis-stimulating agent for the treatment of anemia. Curr Hematol Rep 4: 436-440, 2005.

12. Haselbeck A, Reigner B, Jordan B, Pannier A and Glaspy J: Pre-clinical and Phase I pharmacokinetic and mode-of-action studies of CERA (Continuous Erythropoiesis Receptor Activator), an innovative erythropoietic agent with an extended serum half-life. Proc Am Soc Clin Oncol 22: 748 (Abstract 3006), 2003. 
13. Dougherty FC, Reigner B, Jordan P and Pannier A: Continuous Erythropoiesis Receptor Activator (CERA) provides dose-dependent erythropoietic activity with a prolonged half-life in healthy volunteers. Ann Oncol 15: iii 157 (Abstract 592), 2004.

14. Dmoszynska A, Kloczko J, Rokicka M, Hellmann A, Spicka I and Eid JE: A dose exploration, phase I/II study of administration of continuous erythropoietin receptor activator once every 3 weeks in anemic patients with multiple myeloma receiving chemotherapy. Haematologica 92: 493-501, 2007.

15. Osterborg A, Steegmann JL, Hellmann A, Couban S, Mayer J and Eid JE: Phase II study of three dose levels of continuous erythropoietin receptor activator (C.E.R.A.) in anemic patients with aggressive non-Hodgkin's lymphoma receiving combination chemotherapy. Br J Haematol 136:736-744, 2007.

16. Hirsh V, Glaspy J, Mainwaring P, Manegold C, Ramlau R and Eid JE: Phase II study of two dose schedules of C.E.R.A. (Continuous Erythropoiesis Receptor Activator) in anemic patients with advanced non-small cell lung cancer (NSCLC) receiving chemotherapy. Trials 8: 8, 2007.

17. Osterborg A, Brandberg Y, Molostova V, Losava G, Abdalkadyrov K, Hedenus $\mathrm{M}$ and Messinger D: Randomized, double-blind, placebo-controlled trial of recombinant human erythropoietin, epoetin $\beta$, in hematologic malignancies. Journal of Clinical Oncology 20: 2486-2494, 2002.

18. Crawford J: Anemia and lung cancer. Lung Cancer 38: S75-S78, 2002.

19. Langer CJ, Choy H, Glaspy JA and Colowick A: Standards of care for anemia management in oncology; focus on lung carcinoma. Cancer 95: 613-623, 2002.

20. Cella D: Factors influencing quality of life in cancer patients: anemia and fatigue. Semin Oncol 25: 43-46, 1998.

21. Pirker R, Wiesenberger K, Pohl G and Minar W: Anemia in lung cancer: clinical impact and management. Clin Lung Cancer 5: 90-97, 2003
22. Morère JF: Role of epoetin in the management of anemia in patients with lung cancer. Lung Cancer 46: 149-156, 2004.

23. Ludwig H, Van Belle S, Barett-Lee P, Birgegard G, Bokemeyer C, Gascón P, Kosmidis P, Krzakowski M, Nortier J, Olmi P, Schneider M and Schrijvers D: The European Cancer Anemia Survey (ECAS): a large, multinational, prospective survey defining the prevalence, incidence, and treatment of anemia in cancer patients. Eur J Cancer 40: 2293-2306, 2004

24. Fujisaka Y, Tamura T, Ohe Y, Kunitoh H, Sekine I, Yamamoto N, Nokihara H, Horiike A, Kodama T and Saijo N: Pharmacokinetics and Pharmacodynamics of Weekly Epoetin Beta in Lung Cancer Patients. Jpn J Oncol 36: 477-482, 2006.

25. Nakagawa K, Ozaki T, Satoh T, Miyazaki M, Akashi Y, Terashima M, Fujisaka Y, Tamura T, Fukuoka M and Saijo N: Epoetin Beta Subcutaneous Administration to Lung Cancer Patients with Anemia; Results of Pharmacokinetics/ Pharmacodynamics Study. Jpn J Lung Cancer 47: 313-322, 2007.

26. Tang L, Persky AM, Hochhaus G and Meibohm B: Pharmacokinetic aspects of biotechnology products. J Pharm Sci 93: 2184-2204, 2004.

27. Glaspy J, Henry D, Patel R and et al: Effects of chemotherapy on endogenous erythropoietin levels and the pharmacokinetics and erythropoietic response of darbepoetin alfa: a randomized clinical trial of synchronous versus asynchronous dosing of darbepoetin alfa. Eur J Cancer 41: 1140-1149, Epub 2005 Apr 8.

28. Agoram B, Heatherington AC and Gastonguay MR: Development and evaluation of a population pharmacokinetic-pharmacodynamic model of darbepoetin alfa in patients with nonmyeloid malignancies undergoing multicycle chemotherapy. AAPS J 8: E552-E563, 2006. 